\title{
MiscellaneOUs
}

\section{Wissenschaftler in turbulenten Zeiten: Erinnerungen an Ornithologen, Naturschuetzer und andere Naturkundler [Scientists in troubled times: Memories about Ornithologists, Conservationists and other Naturalists]}

\section{By E. Nowak. 2005. Stock \& Stein Publisher, Schwerin, Germany. 432 pages. Cloth.}

This unique biography book on famous naturalists will make you shiver: If you ever wonder why even great researchers did not get acknowledged, promoted and tenured, read this book. As a monument in time, it is of great value to the general public, to old and to young scientists alike. It is for that reason that I decided to present an English review of this book (as this great book currently only exists in German; Russian translation is planned by the book's author).

In this fascinating publication author E. Nowak presents us with a unique documentation on how politics overrule and interfere with (bird) science and conservation world-wide. Denial of jobs, rejected manuscripts and books, censorship, and personal tragedies are rather familiar to the 15 Germans, 14 Russians, 8 Polish, 2 French, 2 Koreans, as well as Austrian, English, Danish, Czech, Ukrainian, Bulgarian, Chinese, Indian and American scholars of natural history from the $19^{\text {th }}$ and $20^{\text {th }}$ centuries. The book index actually mentions over 700 individual researchers overall and they are directly related to the scholars described. Nowak knew virtually all of them personally, and many stories he compiled are tragic, some end on a somewhat positive note, but all basically tell a story of incredible endurance, persistence, complexity and hard scientific labor; it's for the birds.

As the 432 pages tell us eloquently, even the most famous researchers experience removal from committees, from editorial jobs, and from publication and lecturing at universities. V. Wahl for instance, an inspiring ornithologist from Czechoslovakia, was simply executed 60 years ago because his political opinion was just not "en vogue". Regular prison, war camps, gulags, concentration camps, as well as deaths, tragedies of family members, and suicides of many (bird) scholars and even Ph.D. students are listed in much detail.

The author, E. Nowak, cannot deny his distinctly Polish view when sharing with us his personal accounts of these individuals. But although this book describes mostly the Central European situation (Eastern European Communism, Nazi-Germany) it deals well with England, Korea, New Zealand and also with political giants and their regimes such as Russia, India and China. It captures world history.

Some of the core themes of this book might be G. Niethammer's pro-Nazi work (e.g., his infamous Observations of the Avifauna of Auschwitz), H. Kumerloeve's research career during the Third Reich and his continued support by the DFG ("Deutsche Forschungs Gemeinschaft"; the German Science Foundation) after the war, E. Schaefer's SS ("Sturmstaffel", Germany's infamous Interior Military Police during the Third Reich) support, and the East German H. Dathe's history with the NSDAP ("National Sozialistische Deutsche Arbeiter Partei"; Hitler's Nazi Party). The proud statement from Nobel Prize winner K. Lorenz "we Austrians are the best Nazis of all" might serve the reader as a representative impression of such details. Nowak presents us with the rhetorical question: can we really judge these historical situations and circumstances?

What excites me here is less the party membership issues of relevant ornithologists and scientists of the day, but much more the inherent cultural publication bias that comes with such and closely related scientific value-systems (e.g., stark nationalistic, white race, male and hierarchical world views in ornithology and beyond), and which are still slightly obvious to this very day (e.g., in the German Journal of Ornithology; I also do not understand why the author does not criticize F. Tischler, for instance, nor the German DO-G Deutsche Ornithologen-Gesellschaft; Germany's ornithological society).

"Nerds with binoculars", such as ornithologists, always raise suspicion. Beyond R. Meinertzhagen and his suggested involvement in trying to rescue the Russia Tsar and his family, the notions of secret service and spying come up again and again in this book and form a chapter of its own. The infamous archives of the Stasi ("Staatssicherheit"; the security service of Eastern Germany using public informants and violating human rights) get cited quite a bit (e.g., in the case of E. Rutschke, H. Stubbe, W. Makatsch and H. Dathe). We learn in this book as well that the wellmaintained Archives of the Russian KGB/NKWD, another global heritage by now, have still much information to offer and can be expected to provide us with many surprises for years to come. Further, the book's author points out to us some corrections on Russian researchers regarding views presented in the standard reference by Flint and Rossolimo (1999). This book is history in the making.

Myself, I found these 432 page to be a rather fascinating read, and my personal favorites are, by far, $\mathrm{H}$. C. Johansen and B. K. Stegmann, or the fascinating lives of J. Delacourt, P. Pfeffer, K. Wodzicki, and the Jankowski family. Every naturalist should know about their achievements and life experiences. The book presents a foundation for ornithological textbooks, environmental history and "Wildlife 101" lectures. I am sure that the readers will for instance appreciate learning about Prof. A. N. Formosov, who helped to build in Russia one of the most extensive networks of 
protected areas in the world (!), or about the paper by Prof. N. Gladkow on “Lenin'istic Principles of Nature Conservation" and that he even carried out bird work during the actual Stalingrad battle in World War II [WW2] fighting for the Germans. It's probably of further interest to the global audience to learn how the two zoological gardens in Berlin and their directors got involved competing for what is "the best social system and society in the world". The history of the RAMSAR Convention and its Russian foreplay (only disturbed last minute by the invasion in Prague) gets well described, too.

This book deals a lot with the Weimar Republic, the k.u.k. (Austrian-Hungarian) monarchy, WW1 and WW2, the Korean and Vietnam wars, as well as with Stalin, Hitler and Mao Tse Tung (relevant U.S. events are largely left out unfortunately). One really should disagree though with the value system Nowak frequently presents us with in the text: coming from a noble family is usually labelled as positive, hunting would be the accepted foundation for ornithology, being always well-behaved and soft-spoken is a must, being a tedious and obedient museum-based scholar is even better, working in a narrowly niched-in discipline is the norm, and always staying politically out of trouble would even be better. Such approaches to nature have not halted the global conservation crisis, though. It further sets the stage for a broken but entrenched peer-review system among buddies and insiders; not being performance-based nor embracing interdisciplinary approaches and harming global progress. Many national ornithological unions, trusts and societies still suffer from these very problems and have not moved on, virtually making global conservation problems worse, leaving their large potential unused.

This book further celebrates Old Boys Networks par excellence. However, many of the "Old Boys" were not short of devotion and publications either (E. Stresemann and N. Boew with over 700 publications, each; or G. P. Dementjew and N. Gladkow, who virtually took no week-ends and holidays) and many of them wrote landmark publications setting an odd foundation for a related bird and conservation culture to this very day.

Writing about other people's lives and tragedies requires skill, and is a major task and undertaking. Nowak masters this chore rather convincingly. However, constantly peeking in personal and governmental security archives and trying to find peculiar biographic details might be perceived by some as "Whistle-Blowing." One really would have wished this book would have provided us with insights into the German and other national academies of sciences, and their puppet-like strategies, involving political 180 degree changes throughout history and in recent times. That the so well-informed author politely ignores these things tells us at least something.
This publication actually makes for an oral history book. But Nowak, despite his claim on the book jacket, does not really follow the established rules of this discipline. Instead, Nowak leads us into his own world of what he picked up along the way while working and meeting with people in his diplomatic, international and scientific career, and from seven years of his own specific research. Therefore, this book carries much entertaining gossip. Another rather interesting detail, but mentioned somewhat aside, is presented by the fact that many of the "big names" and people doing fieldwork are either divorced, or marry their field work partner. What also would make for an interesting modern study subject is whether the people Nowak describes have experienced a peculiar mother-father relationship.

Regardless, this book makes a must-read and reference in your book shelf. In times of globalization, it's a unique historical document opening up new ways of thinking about (museum) ornithologists and even conservationists. Young scientists will be interested learning about the years of anxiety researchers had to go through; only few got rich and all worked incredibly hard. Due to all the political pressures and when working with internationally migrating birds, some scientists can indeed be described as Top-Managers "dancing frequently on eggs" and around research and import permits (e.g., in the case of W. Makatsch). The almost bizarre lives of scientists working abroad and between countries are well covered (W. Beick, W. Graf Dzieduszycki, E. Rutschke, W. Makatsch, K. Wodzicki, N. A. Gladkow, besides others).

Nowak makes it a common statement to his readers that parents of the described scholars usually tried to stop their children from becoming ornithologists or biologists. In regimes that turned violent, the professional repressions, as well as career blockage due to political reasons, family background and ideology occurred frequently. This is often played through lack of acceptances and transfers, or forced withdrawals, of university degrees and promotions. Freedom of speech virtually did not exist. It is shown that becoming a party member was often a must for many scholars.

The book shows that people with a personal opinion and strong will were not wanted, and lost their job (e.g., in the case of A. B. Kistiakowskj). It is further shown that "informants" commonly occurred. Betrayals by colleagues, even for Nobel prize awards, get described several times. Often, it's not the censorship as such, but the colleagues themselves and "the faculty" that carried out the pre-screening on behalf of the government then in power.

Unfortunately, the major role the U.S. plays in science and conservation (e.g., via the CIA, FBI and through "modern" commercial and foreign policies) is basically omitted by the author. However, it is mentioned that the U.S. paid for the 1930s German expe- 
ditions for E. Schaefer and E. Stresemann (which basically set up both for their careers).

Finally, a book that describes how scientists of this world have been treated in our current time and by the "Iron Triangle" and the so-called "free Western World" still needs to be written (see Ott 2005 and Stiglitz 2005 for an initial introduction and overview). Appropriately, Nowak cites the ancient Greek philoso- pher Sophokles (in Hipponos): “...hide nothing because the time sees and hears everything, and she will expose it".

FALK HuETTMANN

EWHALE Laboratory, Institute of Arctic Biology, Biology \& Wildlife Department, University of Alaska-Fairbanks, Fairbanks Alaska 99775 USA

\author{
New TITLES \\ Prepared by Roy John \\ $\dagger$ Available for review * Assigned \\ Currency Codes - CAD Canadian Dollars, USD U.S. Dollars, EUR Euros, AUD Australian Dollars.
}

\section{ZoOLOGY}

$\dagger$ The Archeology of Animal Bones. By T. O'Connor. 2008. Texas A\&M University Press, 4354 TAMU, College Station, Texas 77843-4354. 216 pages. 25.95 USD. Paper.

Beaver (Castor Fiber) in Slovenia/Bober (Castor Fiber) in Sloveniji. By B. Krystofek, A.Hudoklin and D. Pavlin. 2006. [In Slovenian]. Pensoft Publishers, Sofia \& Moscow, Geo Milev Str., No 13a, 1111 Sofia, Bulgaria. 41 pages. EUR 20.00 .

Fifty Years of Flukes and Flippers: a Little History and Personal Adventures with Dolphins, Whales and Sea Lions - 1958-2007. By W. Evans. 2008. Pensoft Publishers, Sofia \& Moscow, Geo Milev Str., No 13a, 1111 Sofia, Bulgaria. 147 pages. EUR 20.00

A Review of Phylogeny and Classification of Gerbillinae (Mammalia: Rodentia). Zoologicheskie Issledovaniya No. 9. By I. Pavlinov. 2008. Pensoft Publishers, Sofia \& Moscow, Geo Milev Str., No 13a, 1111 Sofia, Bulgaria. 68 pages. EUR 19.00 .

The Dwarf Hamster Genus Phodopus: Systematics, Phylogeography, Ecology, Physiology, Behaviour, Chemical Communication (Khomyachki Roda Phodopus: Sistematika, Filogeografiya, Ekologiya, Fiziologiya, Povedenie, Khimicheskaya Kommunikatsiya). By N. Feoktistova. 2008. [In Russian with a summary in English]. Pensoft Publishers, Sofia \& Moscow, Geo Milev Str., No 13a, 1111 Sofia, Bulgaria. 414 pages. EUR 76.00.

Principles and Methods of Mammalian Age Determination (Printsipy I Metody Opredeleniya Vozrasta Mlekopitayushchikh). By G. Klevezal. 2007. [In Russian]. Pensoft Publishers, Sofia \& Moscow, Geo Milev Str., No 13a, 1111 Sofia, Bulgaria. 284 pages. EUR 38.00.

The Musk Deer: Ecology, Numbers Dynamics, Prospects for Conservation (Kabarga: Ekologiya, Dinamika Chislennosti, Perspektivy Sokhraneniya). By V. Zaitsev. 2006. [In Russian, summary in English.] Pensoft Publishers, Sofia \& Moscow, Geo Milev Str., No 13a, 1111 Sofia, Bulgaria. 120 pages. EUR 37.00 .
Spatio-ethological Structure of Rodent Populations (Prostranstvenno-etologicheskaya Astrukrura Populyatsii Gryzunov). By V. Gromov. 2008. [In Russian]. Pensoft Publishers, Sofia \& Moscow, Geo Milev Str., No 13a, 1111 Sofia, Bulgaria. 582 pages. EUR 76.00.

Baleen Whales. Mammals of Russia and Adjacent Regions. By V. Sokolov and V. Arsen'ev. 2006. Pensoft Publishers, Sofia \& Moscow, Geo Milev Str., No 13a, 1111 Sofia, Bulgaria. 318 pages. EUR 45.00.

The White Whale, Delphinapterus Leucas, in Russia's Arctic Seas: Biology, Ecology, Conservation and Resource Exploitation (Belukha Delphinapterus Leucas Arkticheskikh Morey Rossii: Biologiya, Ekologiya, Okhrana IIspol'zovanie Resursov). By G. Matishov and G. Ognetov. 2006. [In Russian, summary in English.] Pensoft Publishers, Sofia \& Moscow, Geo Milev Str., No 13a, 1111 Sofia, Bulgaria. 296 pages. EUR 36.00.

The Wild Mammals of Wisconsin. Pensoft Series Faunistica 68. By C. Long. 2008. Pensoft Publishers, Sofia \& Moscow, Geo Milev Str., No 13a, 1111 Sofia, Bulgaria. 524 pages. EUR 78.00.

\section{BOTANY}

* Trees and Shrubs of Minnesota. By Welby R. Smith 2008. University of Minnesota Press Suite 290, 111 Third Avenue South, Minneapolis, Minnesota 55401. 704 pages. 59.95 USD.

\section{OTHER}

* A Mountain Year - A Nature Diary of a Wilderness Dweller. By C. Czajkowski. 2008. Harbour Publishing, Box 219, Madeira Park, British Columbia V0N 2H0. 176 pages. CAD 36.95. Cloth.

* Snakebit. By L. Anthony. 2008. Greystone Books, \#201 2323 Quebec Street, Vancouver, British Columbia V5T 4S7. 288 pages. 29.95 CAD. Cloth. 